\title{
KENAKALAN REMAJA DAN RELIGIUSITAS: MENGUATKAN METAL REMAJA DENGAN KARAKTER ISLAMI
}

\author{
Joko Wibowo \\ STAIN Sultan Abdurrahman Kepulauan Riau \\ joko@stainkepri.ac.id \\ ABSTRAK
}

\begin{abstract}
Fokus kajian artikel ini menitikberatkan pada kajian pentingnya pembentukan karakter dalam diri remaja. Hal ini berangkat dari kenyataan bahwa banyak saat ini bentuk kenakalan remaja begitu beragam, bahkan ada yang mengarah pada tindak kriminal. Penelitian ini hendak mencari jawaban apakah tentang pola pembentukan karakter remaja dengan nilai-nilai religius dari perspektif Islam. Penelitian ini juga menguatkan hasil penelitian sebelumnya yang menyatakan bahwa terdapat korelasi antara nilai religiusitas dalam diri ter hadap kenakalan remaja. Dari penelitian ini dapat digambarkan bahwa usia remaja merupakan usia yang rapuh terhadap pengaruh, baik pengaruh internal dalam diri mapun pengaruh ekternal dari lingkungannya. Pengaruh tersebut bisa berdampak negatif terhadap diri siswa bila tidak diingi dengan penanaman nilai-nilai religius. Karakter yang paling dasar yang harus ditanamkan dalam diri remaja ialah adab atau akhlah, kemudian di susul dengan pengetahuan, dan dilanjutkan dengan penanaman nilai budipekerti sesuai dengan ajaran Islam, seperti kemandirian, amanah, santun, dermawan, optimisme, toleransi dan rendah hati. Remaja juga perlu dibiasan melakukan pebuatan yang mencerminan nilai-nilai karakter religius seperti menolong sesama, peduli lingkungan, gotong royong, dan lain sebagainya. Penanaman nilai-nilai budipekerti berdasarkan nilai Islami ini perdilakukan dilakukan secara formal maupun non formal agar terserap dengan baik oleh setiap remaja.
\end{abstract}

ABSTRAC: The focus of the study of this article focuses on the study of the importance of character formation in adolescents. This departs from the fact that many forms of juvenile delinquency are so diverse, some even lead to criminal acts. This study sought to find answers to whether the pattern of formation of adolescent characters with religious values from an Islamic perspective. This study also corroborates the results of previous studies which stated that there is a correlation between the value of self-religiosity towards juvenile delinquency. From this study it can be described that adolescence is a fragile age to influence, both internal influences within oneself and external influences from the environment. These influences can have a negative impact on students if they are not desired by planting religious values. The most basic character that must be instilled in adolescents is adab or akhlah, then followed by knowledge, and continued with the cultivation of cultural values in accordance with Islamic teachings, such as independence, trustworthiness, courtesy, generosity, optimism, tolerance and humility. Adolescents also need to be encouraged to carry out actions that reflect the values of religious characters such as helping others, caring for the environment, mutual cooperation, and so forth. The cultivation of cultural values based on Islamic values carried out in formal and non-formal ways so that each teenager is well absorbed.

Kata kunci: Budipekerti, Ablak al-karimah, Kenakalan Remaja, Pendidikan Karakter

\section{PENDAHULUAN}

Usia remaja merupakan masa transisi yang pasti akan dilalui oleh setiap manusia untuk menuju proses kedewasaan. Situasi ini rentan akan perubahan-perubahan emosi. Pembentukan karakter dan mental kepribadian dewasa bergantung bagaimana proses transisi masa remaja ini dilewati. Perkembangan psikologis remaja dengan beragam emosinya, juga karap kali mengalami penyimpangan atau tidak berjalan dengan mudah dan sesuai harapan. Fenomena yang cukup nyata ialah kenakalan remaja, yang terus menerus dikeluhkan oleh setiap generasi. Bila generasi hari ini mengeluhkan kenakalan remaja hari ini, sering kali yang terucap ialah, "dulu aku nakal, tapi tidak parah kali seperti remaja saat ini." Bahasa demikian telah mengindikasikan bahwa kenakalan remaja itu menjadi bagian dari proses pendewasaan. 
Kenakalan remaja masa kini yang kerap dikeluhkan oleh masyarakat karena tingkah dan perbuatan mereka terkadang mementingkan diri sendiri dan juga tidak peduli terhadap keselamatan diri serta orang lain. Meskipun telah cukup lama dikeluhkan, namun fenoma ini tidak kunjung hilang. Bahkan terus bermetamorfosa mengikuti perkembangan zaman. Jika dahulu kenakalan remaja lebih pada perilaku yang tidak sesuai dengan adat kebiasan, namun kini sudah mengarah pada tindak kriminalitas dan membahayakan orang lain. Maka, kenakalan remaja sebagai kumpulan dari berbagai perilaku, dari perilaku yang tidak dapat diterima secara sosial sampai tindakan kriminal.

Bentuk kenakalan remaja dapat digolongkan menjadi dua, yakni kenalakan pelanggan hukum dan kenakalan kriminal. Yang pertama masuk dalam kenakalan yang tidak dapat digolongkan pada pelanggaran hukum. ${ }^{1}$ Kenakalan tersebut termasuk amoral, asosial maupun norma, yaitu pelanggaran terhadap moral, dan melanggar terhadap aturan dan norma yang berlaku di masyarakat, serta pelanggaran terhadap aturan agama. Sebagai contoh pergaulan buruk, menonton video porno dan masih banyak lagi. Sedangkan kenakalan yang dapat digolongkan terhadap hukum mengarah kepada tindakan kriminal. Seperti percobaan pembunuhan, penyekapan, penganiayaan, mencuri, merampok, memperkosa, pelecehan seksual lainnya, dan masih banyak lagi.

Sebagaimana dikutip Sarwono, Jensen juga membagi kenakalan remaja menjadi empat kategori. ${ }^{2}$ Pertama, perilaku yang melanggar hukum, seperti melanggar ramburambu lalu lintas, mencuri, merampok, memperkosa dan masih banyak lagi perilakuperilaku yang melanggar hukum lainnya. Kedua, perilaku yang membahayakan diri sendiri dan orang lain seperti merokok dan mengonsumsi narkoba. Ketiga, perilaku yang

1 Fatwa Tentama, "Achievement Motivation Training (AMT) Sebagai Upaya Mencegab Kenakalan Remaja" Prosiding (November 8, 2017). doi:10.31227/osf.io/ucqw9. h.12

2 Sarwono, S.W. (2010). Psikologi Remaja, Jakarta: Rajawali Pers. h. 24 menimbulkan korban materi seperti mencuri, memalak, merusak fasilitas sekolah maupun fasilitas umum lainnya dan lain-lain. Dan keempat, perilaku yang menimbulkan korban fisik seperti tawuran atau berkelahi. Fenanoma itu semua bisa didapati dengan mudah bagi yang memperhatikan perkembangan informasi melalui internet. Bahkan, jejak-jejak kenakalan remaja begitu beragam sehingga menimbulkan rasa kekhawatiran di kalangan orang tua.

Pembentukan mental yang kurang tepat di kalangan remaja bisa menimbulkan penyimpangan, seperti kenalanan remaja. Sedangkan pembentukan mental itu setidaknya memiliki beberapa pola, yakni pembentukan melalui nilai-nilai agama, pembentukan melalui pendidikan formal, pembentukan melalui lingkungan sekitar. Dalam hal ini, agama menjadi sumber penting dalam pembentukan karekater karena sejatinya agama merupakan sumber nilai kebajikan. Dampaknya ialah nilai-nilai religiusitas yang terinternalisasi dalam diri dan terpraktik dengan prilaku sehari-hari berupa ahlak yang mulia. Proses internalisasi terhadap nilai-nilai agama kerkaitan erat dengan kepercayaan terhadap ajaran-ajaran agama, baik dalam keyakinan maupun dalam prilaku. Menurut Ancok dan Suroso, yang mengutip dari Glock dan Stark, empat hal yang berkaitan dengan religiusitas meliputi hal-hal dimensi keyakinan ideologis, dimensi praktik agama, dimensi pengalaman religius, dimensi pengetahuan agama, dan dimensi konsekuensi. ${ }^{3}$

Problematika kenakalan remaja menjadi pembahasan penting di kalangan pengkaji psikologi perkembangan sebab tidak lepas dari perkembangan fenomena sosial dan gaya hidup masyarakat masa kini. Para peneliti juga telah menelaah tentang pengaruh teknologi terhadap kenalanan remaja. Selain itu, selama ini faktor penyebab prilaku kenakalan selalu dikaji dari sisi eksternal individu. banyak teori yang menganggap bahwa prilaku menyimpang,

3 Ancok, D. \& Suroso, F.N, (2011), Psikologi Islami Solusi Islam atas Problem problem Psikologi. Yogyakarta: Pustaka Pelajar. 
terutapa kejahatan, adalah hasil belajar individu dari lingkungan atau tekanan dari suatu keadaan tertentu. Hal ini menambah panjang deretan pertanyaan teoritis dan akademis perihal upaya mengkaji lebih lanjut tentang kenalan remaja dan pengaruhnya dalam peraktik keagamaan sebagai upaya menyelidik faktor internal dari nilai-nilai agama. Penelitian ini akan memfokuskan pada upaya menanggulangi kenalan remaja melalui pendekatan agama dalam pembentukan mentalnya. Dalam konteks ini digunakan kajian litelatur dalam upaya menggali khazanah pengatuan dari perspektif normatif Islam dalam memotret fenomena psikologi perkembangan remaja.

\section{Mental dan Kepribadian Remaja}

Mental dan karakter merupakan dua kata yang memiliki makna serupa namun tidak sama. Beberapa pengertian yang diajukan oleh para pakar juga tidak sama, namun memiliki benang berang yang serupa. Kata "mental" berasal dari bahasa Latin yaitu dari kata mens atau metis yang memiliki arti jiwa, nyawa, sukma, roh, semangat. Kata ini semakna dengan kata psyche, yakni psikis, jiwa ataupun kejiawaan. ${ }^{4}$ James Draver memaknai mental yaitu "revering to the mind" maksudnya adalah sesuatu yang berhubungan dengan pikiran atau pikiran itu sendiri. ${ }^{5}$ Secara sederhana mental dapat dipahami sebagai sesuatu yang berhubungan dengan batin dan watak atau karakter, tidak bersifat jasmani (badan). ${ }^{6}$

Beberapa pakar juga memiliki definisi yang berbeda, seperti Al-Quusy (1970) yang dikutip oleh Hasan Langgulung, mendefinisikan mental ialah paduan psikologis yang menimpa manusia yang dapat berpengaruh terhadap emosi dan dari emosi ini akan mempengaruhi pada kondisi

4 Moeljono Notosoedirjo, Kesehatan Mental: Konsep dan Penerapan, (Malang: Universitas Muhammadiyah, 2001), hlm. 21

${ }^{5}$ James Draver, A Dictionary of Psychology, (New York: Pengin Books, t.th.), hlm. 169

6 Tim Penyusun Pusat Pembinaan Pengembangan Bahasa, Kamus Besar Bahasa Indonesia, Edisi Kedua (Jakarta: Balai Pustaka, 1994), hlm. 646. mental. $^{7}$ Dari sini dapat ditarik pengertian yang lebih signifikan bahwa mental itu terkait dengan, akal (pikiran/rasio), jiwa, hati (qalbu), dan etika (moral) serta tingkah laku). Hal inilah yang menjadi landasan dalam membentuk mentalitas atau kepribadian (citra diri) sehingga baik dan jelek tergantung pada mentalitas yang dibuatnya. Dengan demikian mental ialah hal-hal yang berkaitan dengan psycho atau kejiwaan yang dapat mempengaruhi perilaku individu. Setiap perilaku dan ekspresi gerak-gerik individu merupakan dorongan dan cerminan dari kondisi (suasana) mental. Kondisi individu kelihatan gembira, sedih, bahkan sampai hilangnya gairah untuk hidup ini semua tergantung pada kapasitas mental dan kejiwaannya.

Para pakar membagi kondisi mental menjadi dua bagian, yakni kondisi mental yang sehat dan kondisi mental yang tidak sehat. Mental yang sehat akan melahirkan pribadi-pribadi yang normal, yakni bentuk tingkah laku individu yang tidak menyimpang dari tingkah laku pada umumnya dimana seorang individu itu tinggal, dan pribadi yang normal akan menunjukkan tingkah laku yang serasi dan tepat (adekuat) dan bisa diterima oleh masyarakat secara umum, dimana sikap hidupnya sesuai dengan norma dan pola hidup lingkungannya. Secara sederhana individu tersebut mampu beradaptasi secara wajar dan normal.

Sementara itu, yang perlu mendapatkan perhatian dan perlu diwaspadai oleh setiap individu ialah kondisi mental yang tidak sehat, karena kondisi mental yang tidak sehat itu akan membentuk suatu kepribadian yang tidak sehat pula (abnormal). Pribadi yang tidak sehat (abnormal) ialah adanya tingkah laku seseorang atau individu yang sangat mencolok dan sangat berbeda dengan tingkah laku umum yang ada di lingkungannya, atau disebut juga dengan perilaku-perilaku yang menyimpang (abnormal). Hal demikian ini sangat rentan

7 Hasan Langgulung, Teori-teori Kesehatan Mental, (Jakarta: Pustaka Al-Husna, 1992), hlm. 30 
sekali menimpa ramaja yang masih dalam status masa perkembangan. Dalam posisi seperti inilah, mentalitas dan karakter memiliki keeratan makna.

Pada dasarnya untuk mengetahui apakah seseorang atau individu sehat mentalnya atau tidak (terganggu mentalnya) tidaklah mudah diukur atau diperiksa dengan alat-alat seperti halnya pada penyakit jasmani, akan tetapi yang menjadi ukuran adalah merasakan diri kita sejauh mana kondisi perasaan kita apakah sudah melampaui batas kewajaran atau tidak seperti, rasa bersedih, kecewa, pesimis, rendah diri dan lain sebagai. Dan seseorang atau individu yang terganggu kesehatan mentalnya, bisa dilihat pada tindakannya, tingkah lakunya atau ekspresi perasaannya, karena seseorang atau individu yang terganggu kesehatan mentalnya ialah apabila terjadi kegoncangan emosi, kelainan tingkah laku atau tindakannya. ${ }^{8}$ Dalam posisi ini, remaja sangat rentan sekali mengalami penyimpangan perkembangan karena pengaruh yang mampu menggerakkan mentalnya.

Beberapa peneliti menilai bahwa kenakalan remaja sebagai kegagalan dalam pemenuhan tugas perkembangan. Pada usia perkembangan ini, beberapa anak bisa mengalami kegagalan dalam mengembangkan kontrol diri yang sudah dimiliki orang lain seusianya. Havigurst menyatakan bahwa salah satu tugas perkembangan remaja ialah bertanggung jawab sebagai warga negara, mencapai tingkah laku yang bertanggung jawab sosial, serta berkembang dalam pemaknaan nilai-nilai yang ada di masyarakat. ${ }^{9}$ Keberhasilan dalam pemenuhan tugas perkembangan ini akan menjadikan remaja sadar dan peka terhadap norma, sehingga remaja mampu mengendalikan kebutuhan pemuasan dorongan-dorongan dalam dirinya agar tidak melanggar norma dan aturan yang berlaku. Dampak negatifnya

8 Zakiyah Daradjat, Kesehatan Mental, (Jakarta: CV Haji Masagung, 1990), hlm. 16

9 Aroma, I. S., \& Suminar, D. R. (2012). Hubungan antara tingkat kontrol diri dengan kecenderungan perilaku kenakalan remaja. Jurnal Psikologi Pendidikan dan Perkembangan, 1(2), 1-6. akan menyebabkan remaja menjadi individu yang kurang peka terhadap aturan dan norma yang berlaku di masyarakat. Individu seperti ini sangat rentan terhadap prilaku melanggar aturan bahkan melakukan tindak kriminal.

Dapat ditarik kesimpulan bahwa mental ialah sesuatu dalam diri seseorang yang terkait dengan psikis atau kejiwaan yang dapat mendorong terjadinya tingkah laku dan membentuk kepribadian. Begitu juga sebaliknya, mental yang sehat juga akan memunculkan kepribadian yang sehat pula. Mental, sangat erat kaitannya dengan karakter ataupun kepribadian. Sigmund Freud memberikan definisi bahwa kepribadian yang sehat adalah adanya keseimbangan antara dorongan-dorongan dan motif-motif tiap bagian jiwa dalam pemuasannya. Begitu juga Arthur Gorden melihat bahwa kemampuan mengharmoniskan dorongan-dorongan psikis dengan realitas dengan sendirinya akan terbentuk kepribadian yang sehat dan akan melahirkan tingkah laku yang sehat pula (normal). ${ }^{10}$

\section{Karakter Religiusitas}

Ahlak merupakan bentuk jamak dari $k$ kulq, yang secara etimologi berarti kebiasaan, prilaku, sifat dasar dan perangai. Dari beberapa kata ini dapat dilihat bahwa ia merupakan sifat dasar yang dimiliki oleh seseorang. Selain beberapa sifat itu, dalam kamus Mu’jam Lisan Al-Arab menambahkan bahwa ahlak merupakan agama sebab di dalamnya terdapat perintah, larangan serta arahan guna perbaikan seseorang. ${ }^{11}$ Menurut Al-Ghazali, kata khuluq dan khalqu adalah dua sifat yang dapat dipakai bersama. Jika menggunakan kata khalqu maka yang dimaksud adalah bentuk lahir, sedangkan jika menggunakan kata khuluq maka yang dimaksud adalah bentuk batin. Karena manusia tersusun dari jasad yang dapat disadari adanya dengan kasat mata (bashar), dan dari ruh dan nafs yang dapat disadari

${ }^{10}$ F. Patty, dkk, Pengantar Psikologi Umum, (Surabaya: Usaha Nasional, 1982), hlm. 189-190

11 Ahmad Hifdzil Haq, Yoke Suryadarma. "Pendidikan Akblak Menurut Imam Al-Ghazali" AtTa'dib, Volume 10 Number 2 (8 December 2015) doi:http://dx.doi.org/10.21111/at-tadib.v10i2.460 
adanya dengan penglihatan mata hati (bashirab), sehingga kekuatan nafs yang adanya disadari dengan bashirah lebih besar dari pada jasad yang adanya disadari dengan bashar.

Secara terminologi, ahlak merupakan sifat yang tumbuh dan menyatu di dalam diri seseorang. Dari sifat yang ada itulah terpancar sikap dan tingkah laku perbuatan seseorang, seperti sabar, kasih sayang, atau sebaliknya pemarah, benci karena dendam, iri dengki, sehingga memutuskan hubungan silaturrahmi. ${ }^{12}$ Al-Ghazali mengartikan ungkapan tentang sesuatu keadaan yang tetap didalam jiwa, yang darinya muncul perbuatan-perbuatan dengan mudah dan gampang, tanpa membutuhkan pemikiran dan penelitian. Apabila dari keadaan ini muncul perbuatan-perbuatan baik dan terpuji menurut akal dan syariat seperti halnya jujur, bertanggung jawab, adil dan lain sebagainya, maka keadaan itu dinama kan ahlak yang baik, dan apabila yang muncul perbuatan-perbuatan buruk seperti berbohong, egois, tidak amanah dan lain sebagainya, maka keadaan itu dinamakan ahlak yang buruk. Dalam kehidupan seharihari, ahlak sering diidentifikasikan dengan moral dan etika. Apabila ditelisik lebih jauh, Ahlak sebenarnya berbeda dari formula moral atau etika, kerena ahlak lebih menunjukkan kepada situasi batiniah manusia. Ahlak juga berarti berkurangnya suatu kecenderungan manusia atas kecendrungan-kecendrungan lain dalam dirinya, dan berlangsung secara terusmenerus itulah ahlak. ${ }^{13}$

Istilah-istilah lain yang sering dikaitkan atau menjadi sinomim dengan ahlak, seperti moral, etika, karakter, dan lain sebagainya. Dalam Kamus Bahasa Indonesia kata "karakter" diartikan dengan tabiat, sifat-sifat kejiwaan, ahlak atau budi pekerti yang membedakan seseorang dengan yang lain, dan watak. Karakter juga bisa berarti

12 Abdullah salim, Akblaq Islam, (Media dakwah, Jakarta: 1986), h. 5

13 Ahmad Amin, Etika (Ilmu Akblak), alih bahasa oleh Prof. K.H. Farid Ma'ruf, Jakarta, Bulan Bintang: 1986), h. 62 beberapa simbol yng digunakan dalam pola komunikasi tulis, seperti huruf, angka, ruang, simbul khusus yang dapat dimunculkan pada layar dengan papan ketik. ${ }^{14}$ Dapati disimpulkan bahwa orang berkarakter berarti orang yang berkepribadian, berperilaku, bersifat, bertabiat, atau berwatak dan makna seperti itu berarti karakter identik dengan kepribadian atau ahlak. Maka dalam kajian ini, kepribadian semakna dengan karakteristik atau sifat khas seseorang.

Meski demikian, ada beberapa pendapat yang memiliki pemahaman berbeda perihal karakter atau kepribadian ini. Sebagian berpendapat bahwa baik buruknya karakter manusia sudah menjadi bawaan dari lahir sehingga manusia itu akan berkarakter baik bila bawaan lahirnya memang baik. Sedangkan sebaliknya, manusia bawaannya jelek jika karakter awal bawaannya jelek. Dalam kelompok yang bependapat demikian ini, maka pendidikan karakter tidak ada gunanya, karena tidak akan mungkin merubah karakter orang yang sudah taken for granted. Sementara itu, sebagian yang lain berpendapat berbeda, yakni bahwa karakter bisa dibentuk dan diupayakan sehingga pendidikan karakter menjadi bermakna untuk membawa manusia dapat berkarakter yang baik. Karakter yang baik dalam islam ialah karakter yang disebut dengan ablak al-karimah atau ahlak yang mulia.

Islam bersumber pada Al-Qur'an dan Sunnah yang juga merupakan sumber untuk menentukan ahlak dalam Islam. Tolok ukur perbuatan baik dan perbutan buruk adalah baik dan buruk menurut kedua sumber itu, bukan baik dan buruk menurut ukuran (akal) manusia. Sebab jika ukurannya adalah manusia, maka baik dan buruk itu bersifat relatif atau berbeda-beda. Seseorang mengatakan bahwa sesuatu itu baik, tetapi orang lain belum tentu menganggapnya baik. Begitu juga sebaliknya, seseorang menyebut sesuatu itu buruk, padahal yang lain bisa saja menyebutnya baik. Melalui kedua sumber

14 Pusat Bahasa Depdiknas, Kamus Besar Bahasa Indonesia, Jakarta: Pusat Bahasa Depdiknas 2008: 682) 
ajaran Islam itulah dapat dipahami bahwa sifat-sifat sabar, tawakkal, syukur, pemaaf, dan pemurah termasuk sifat-sifat yang baik dan mulia. Sebaliknya, dipahami juga bahwa sifat-sifat syirik, kufur, nifaq, ujub, takabur, dan hasad merupakan sifat-sifat tercela. Jika kedua sumber itu tidak menegaskan mengenai nilai dari sifat-sifat tersebut, akal manusia mungkin akan memberikan penilaian yang berbeda-beda.

Namun demikian, Islam tidak menafikan adanya standar lain selain alQuran dan Sunnah untuk menentukan baik dan buruk Ahlak manusia. Standar lain yang dapat dijadikan untuk menentukan baik dan buruk adalah akal dan nurani manusia serta pandangan umum masyarakat. Dengan hati nuraninya, manusia dapat menentukan ukuran baik dan buruk, sebab Allah memberikan potensi dasar kepada manusia berupa tauhid. Artinya, ada hal-hal yang memiliki nilai universal dalam menentukan suatu yang baik sehingga nilai-nilai itu pun akan selaras dengan nilai Islam.

Bentuk standar dari karakter islami telah banyak dirumuskan oleh cendekia mulsim. Mereka menggalinya dari al-Qur'an dan Sunnah untuk mendapatkan tolok ukur standar yang bisa dijadikan patokan sebagai karakter religius. Berkaitan dengan berbagai bentuk Ahlakul karimah, menurut Ibnu Miskawaih sebagaimana disebutkan Ibrahim Nasbi, ada bentuk yang beragam, seperti kearifan, kesederhanaan, keberanian, kedermawanan dan keadilan. ${ }^{15}$ Dalam kearifan ada kepandaian (al-draka), ingat (aldzikru), berfikir (al-ta'aqqu), kejernihan pikiran (shafau al-dzihni), ketajaman dan kekuatan otak (jaudat al-dribni), dan kemampuan belajar dengan mudah (subulat at-ta'allum). Dalam kesederhanaan terdapat rasa malu (al-haya), tenang (al-da'at), sabar (as-shabru), dermawan (al-sakha), integritas (al-burriyah), puas (al-qana'ab), loyal (aldamatsab), berdisiplin diri (al-intizham), optimis atau berpengharapan baik (busn-albuda), kelembutan (al-musalamab), anggun berwibawa (al-wiqar), dan wara. Dalam

15 Nasbi, Ibrahim. (2015). Filsafat al-Nafs dan Filsafat al-Akblak. Shaut al Arabiyyah, 4(1), 16-24. keberanian terpatri kebesaran jiwa, tegar, ulet, tabah, menguasai diri, dan perkasa. Dalam kedermawanan tertanam sifat murah hati (al-karam), mementingkan orang lain (alitsar), rela (al-nail), berbakti (al-muwasab), dan tangan terbuka (al-samabab). Dan dalam keadilan terdapat rasa persahabatan, bersemangat sosial (al-ulfah), silaturrahmi, memberi imbalan (mukafa'ab), baik dalam bekerja sama (busn al-syarikah), kejelian dalam memutuskan persoalan (busn al-qadha), cinta (tawaddu), beribadah kepada Allah, dan takwa kepada Allah.

Bentuk ahlak terpuji itu banyak sekali setiap orang menginginkan untuk memilikinya. Rasulullah Saw menganjurkan umatnya agar memilikinya. Beberapa bentuk aklah terpuji itu juga berkaitan dengan sifatsifat terpunji. Ada beberapa sifat terpunyi yang perlu dimiliki oleh manusia untuk menguatkan ahlak al-karimah yang mencontoh dari sifat-sifat Allah sebagaimana disebutkan oleh Hamzah Tualeka. ${ }^{16}$ Pertama, sifat sabar, yakni menjadi sifat yang perlu ditanam dalam diri setiap manusia. Ada peribahasa mengatakan bahwa kesabaran itu pahit dilaksanakan, namun akibatnya lebih manis daripada madu. Ungkapan tersebut menunjukkan hikmah kesabaran sebagai fadhillah kesabaran dapat dibagi menjadi empat kategori: sabar dalam menanggung beratnya melaksanakan kewajiban, sabar menanggung musibah atau cobaan, sabar menahan penganiayaan dari orang, sabar menanggung kemiskinan.

Kedua, sifat jujur (shidq). Di dalam peribahasa sering disebutkan: berani karena benar takut karena salah. Betapa ahlak alkarimah menimbulkan ketenangan batin yang dari situ dapat melahirkan kebenaran. Rasulullah saw. telah membrikan contoh betapa beliau berani dalam berjuang karebna beliau yakin sedang berjalan di atas prinsipprinsip kebenaran. Benar ialah memberitahukan (menyatakan) sesuatu yang

${ }^{16}$ Hamzah Tualeka, Abd. Syakur dkk, Akblak Tasawnf, (Surabaya: IAIN Sunan Ampel, 2012 ), hal. 158-167 
sesuai dengan apa adanya, artinya sesuai dengan kenyataan.

Ketiga, sifat amanah, yang menurut berarti kesetiaan, ketulusan hati, kepercayaan atau kejujuran. Kebalikannya ialah khiyanah. Khiyanah adalah salah satu gejala muunafik. Betapa pentingnya sifat dan sikap amanah yang dipertahankan sebagai Ahlak karimah dalam masyarakat. Jika sifat dan sikap itu hilang dari tatanan sosial umat Islam, maka kehancuran yang bakal terjadi bagi umat itu.

Keempat, sifat adil, yakni dalam konteks ini berhubungan dengan perseorangan, adil berhubungan dengan kemasyarakatan dan juga adil itu berhubungan dengan pemerintah. Adil perseorangan ialah tindakan hak kepada yang mempunyai hak. Bila seseorang mengambil haknya dengan cara benar atau memberikan hak orang lain tanpa mengurangi haknya, itulah yang dinamakan tindakan adil. Adil yang berhubungan dengan kemasyarakatan dan adil yang berhubungan dengan pemerintahan. Misalnya, tindakanhakim menghukum orang-orang jahat atau orang-orang yng bersengketa sepanjang neraca keadilan.

Kelima, sifat kasih dan sayang sebagai fitrah yang dianugrahkan Allah kepada makhluk-Nya. Pada hewan, misalnya, begitu kasihnya pada anaknya, sehingga rela berkorban jika anaknya terganggu, naluri ini pun ada pada manusia, mulai dari kasih sayang orang kepada anaknya dan sebaliknya, kecintaan dan hormat anak pada orang tuannya. Manakala sifat terhujam kuat dalam diri pribadi seseorang, maka dapat menimbulkan berbagai Ahlak al-mahmudah lainya, antara lai sebagai berikut: pemurah, tolong menolong, pemaaf, damai, persaudaraan dan jiwa yag penuh dengan kasih sayang, dan menghubungkan tali kekeluargaan.

Keenam, sifat hemat, yakni menggunakan segala sesuatu yang tersedia berupa harta benda, waktu, dan tenaga menurut ukuran keperluan, mengambil jalan tengah, tidak kurang dan tidak berlebihan. Adapun macammacam penghematan antara lain sebagai berikut: penghematan harta benda, penghematan tenaga. Dan penghematan waktu.

Ketujuh, sifat berani (syaja'ah), yaitu sikap menujukan keberanian dalam menegakan hal-hal yang baik dan menolak perkara yang mungkar. Berani bukanlah semata-mata berani berkelahi ke medan laga, melainkan sikap melainkan suatu sikap mental seseorang yang dapat menguasai jiwanya dan berbuat menurut yang semestinya. Orang yang dapat menguasai jiwannya pada masa-masa kritis ketika bahaya di ambang pintu itulah orang byang berani. Rasulullah bersabda, "Bukanlah yang dinamakan pemberani, orang yang kuat bergulat. Sesungguhnya pemberani itu ialah orang yang sanggup menguasai hawa nafsunya dikala marah". (HR. Ahmad)

Kedelapan bersifat kuat (al-quwwah), yakni kekuatan yang besrsifat fisik dan juga bersifat nonfisik. Alkarimah, seperti kuat fisik, kuat jiwa dan kuat akal pikiran, cerdas dan mengambil keputusan yang tepat. Kekuatan ini hendaknya dibina dan diikhtiarkan supaya bertambah dalam diri, dapat dipergunakan meningkatkan amal perbuatan. Tambahan kekuatan itu dapat diperoleh selain usaha fitrah atau jalan yang wajar, juga memohon kepada Allah swt. Sungguh atas kehendak Allahlah semua terwujud, tiada kekuatan kecuali dengan pertolongan Allah.

Kesembilan, sifat malu (al-haya) yang diartikan sebagai sifat malu terhadap Allah dan malu kepada diri sendiri di kala melanggar peraturan-peraturan Allah. Perasaan ini dapat menjadi bimbingan menuju jalan keselamatan dan mencegah dari perbuatan nista. Tentu dalam hal ini juga malu bila melakukan tindakan atau perbuatan yang melanggar norma-norma agama dan sosial yang berlaku di masyarakat.

Kesepuluh, memelihara kesucian diri (al-íffab), yang juga bagian penting dari sifat yang perlu di tanam dalam diri. Kesucian yang dimaksud ini adalah kesucian luar dhahir dan batin. Memelihara kesucian diri termasuk dalam rangkaian Ahlak karimah yang dituntut dalam ajaran Islam. Menjaga diri dan segala keburukan dan memelihara kehormatan hendaklah dilakukan pada setiap 
waktu. Dengan penjagaan diri secara ketat, maka dapatlah diri pertahankan untuk selalu berada pada status khair annas (sebaik-baik manusia). Hal ini dilakuakan mulai dari memelihara hati (qalb) untuk tidak berbuat rencana dan angan-angan yang buruk.

Terdapat banyak sekali nilai-nilai suri tauladan yang perlu diresapi setiap umat Islam agar menjadi karakter yang tertanam pada dirinya. Semua itu bersumber dari AlQur,an dan Sunnah. Oleh sebab itu, karakter islami bagi umat Islam ini memang sejatinya tidak hanya pada orang dewasa saja, melainkan juga ditanamkan sedari kecil. Remaja, sebagai usia perkembangan atau masa pubertas juga perlu menanamkan nilainilai religius dalam diri agar menjadi karakter dan kepribadiannya dalam bergaul dengan masyarakat. Apalagi, kondisi sosial dan latar lingkungan setiap orang juga mengubah orang lain. Faktor-faktor yang mempengaruhi karakter religius ini juga masih perlu menjadi perhatian agar tidak melunturkan karakter yang sudah tertanam.

Menurut Thouless, sebagaimana dikuti oleh Nur Azizah, terdapat empat kelompok yang mempengaruhi perkembangan religiusitas. Pertama, faktor sosial yang meliputi semua pengaruh sosial seperti; pendidikan dan pengajaran dari orangtua, tradisi-tradisi dan tekanan-tekanan sosial. Kedua faktor alami, yang meliputi moralitas dari pengalaman-pengalaman baik yang bersifat alami, seperti pengalaman konflik moral maupun pengalaman emosional. Ketiga, faktor kebutuhan untuk memperoleh harga diri dan kebutuhan yang timbul karena adanya kematian. Keempat, faktor intelektual yang menyangkut proses pemikiran verbal terutama dalam pem bentukan keyakinan-keyakinan agama. ${ }^{17}$

Pengaruh yang demikian ini bisa saja terjadi pada semua usia. Mungkin pernah ada seseorang yang bertaubat saat usia sudah menginjak kepala lima, bisa jadi remaja yang baru berusa belasan tahun menjadi seorang

17 Azizah, Nur. "Perilaku Moral dan Religiusitas Siswa Berlatar Belakang Pendidikan Umum dan Agama" Jurnal Psikologi, Volume 33 Number 2 (21 May 2013) pembunuh. Hal ini adalah faktor-faktor eksternal yang bisa mempengeruhi diri seseorang yang melunturkan nilai-nilai religius yang semestinya tertanam dalam dirinya. Nabi berpesan agar keimanan yang menjadi karakter religius muslim tetap harus dijaga sebab kadarnya bisa naik dan bisa saja turun. Hal inilah pentingnya kalangan remaja muslim untuk menguatkan karakter religius sehingga mental dan kribadiannya akan sejalan dengan nilai-nilai Islam.

\section{Membangun Remaja Bermental Riligius}

Pertanyaan sederhana yang perlu diulang ialah, apakah religiusitas berpengaruh terhadap mental dan karakter? Banyak penelitian yang menunjukkan bahwa agama dapat menjadi kekuatan positif untuk kesehatan fisik dan mental. Penelitian yang menghubungkan religiusitas dan perilaku moral mempunyai hasil yang positif sehingga dapat mendasari proses dan pengaruh agama apabila disesuaikan dengan proses sosial pada ukuran perilaku moral dan sikap. ${ }^{18}$ Dalam hal ini, peniliti menilai bahwa Agama mempunyai peran penting dalam mengelola stres, agama dapat memberikan individu pengarahan/bimbingan, dukungan, dan harapan, seperti halnya pada dukungan emosi. Melalui berdoa, ritual dan keyakinan agama dapat membantu seseorang dalam koping pada saat mengalami stres kehidupan, karena adanya pengharapan dan kenyamanan. Menurut Nur Azizah, religiusitas remaja di sekolah umum dan sekolah agama sama saja. ${ }^{19}$

Kenakalan remaja adalah kecenderungan remaja untuk melakukan tindakan yang melanggar aturan yang dapat mengakibatkan keru-gian dan kerusakan baik terhadap dirinya sendiri maupun orang lain yang dilakukan remaja rentang usia 13-17 tahun. Remaja yang berperilaku nakal diindikasikan memiliki tingkat religiusitas

18 Utami, M. (2014). Religiusitas, Koping Religius, dan Kesejabteraan Subjektif. Jurnal Psikologi, 39(1), 46-66. doi:https://doi.org/10.22146/jpsi.6966

19 Azizah, Nur. "Perilaku Moral dan Religiusitas Siswa Berlatar Belakang Pendidikan Umum dan Agama" Jurnal Psikologi[Online], Volume 33 Number 2 (21 May 2013) 
yang rendah dan control diri yang rendah. Salah satu faktor yang mempengaruhi kenakalan remaja adalah kontrol diri. Menurut hasil penelitian Azizah, remaja yang gagal dalam mengembangkan kontrol diri yang cukup dalam hal tingkah laku berarti gagal dalam mempelajari perilaku yang dapat diterima dan perilaku yang tidak dapat diterima oleh masyarakat. Kontrol diri menggambarkan keputusan individu yang melalui pertimbangan koqnitif untuk menyatukan perilaku yang telah disusun untuk mening-katkan hasil dan tujuan tertentu seperti yang diinginkan. Individu dengan kontrol diri tinggi sangat memperhatikan cara-cara yang tepat untuk berperilaku dalam situasi yang bervariasi. Remaja yang memiliki control diri tinggi cenderung akan menghindari perbuatan nakal dan tidak akan terbawa arus pergaulan lingkungannya.

Para peneliti juga mengungkapkan bahwa semakin tinggi tingkat religiusitas remaja maka semakin rendah kenakalan remaja, sebaliknya semakin rendah tingkat religiusitas remaja maka semakin tinggi kenakalan remaja. Sedangkan hipotesa lainnya yang mengkaji tentang kontrol diri remaja dan kenakalan remaja juga menemukan korelasi bahwa semakin mawas diri seseorang, maka akan semakin berkurang kenakalannya. Hal ini berangkat dari asumsi bahwa setiap individu memiliki suatu mekanisme yang dapat membantu mengatur dan menga-rahkan perilaku, yaitu kontrol diri. Kontrol diri dapat diartikan sebagai kemampuan untuk mengontrol perilaku impulsive, mengontrol stimulus, mengantisipasi suatu peristiwa dan mengambil keputusan. Kontrol diri ini yang bagusdapat membawa individu ke arah konsekuensi positif.

Melihat kenyataan tersebut, maka memang pentinglah karakter dan mental religius di kalangan remaja. Sebagaiman telah diulas di atas, bahwa nilai-nilai dalam agama bija menjadi bagian dari pembentuk karakter seseorang, maka menambah pemahaman terhadap ajaran dan nilai agama itu merupakan upaya menanamkan karakter dalam diri remaja. Nilai-nilai religius dalam
Islam sebagaimana telah disebutkan di bagian awal perlu ditanamkan tingkat kenakalan dalam remaja menjadi bekurang. Setidaknya, penelitian-penelitian yang telah dilakukan sebelumnya perlu menjadi pijakan bahwa pendidikan karakter berbasiskan ahlak al-karimah sangat penting bagi remaja.

Pendidikan ahlak merupakan inti dari pendidikan. Ahlak mengarahkan pada perilaku. Ahlakul karimah adalah tatkala perilaku manusia mengikuti aturan Islam dalam setiap aspek kehidupan, sebagaimana terimplikasi dalam hadits 'Aisyah ra yang artinya "Ahlak Rasulullah Saw adalah alQur'an" (HR. Muslim). Adapun pendidikan di luar pendidikan Ahlak hanya bersifat teknis atau life-skill (keterampilan hidup). Hal inilah pentingnya pendidikan dalam perspektif Islam, yakni tidak saja menitik beratkan pada unsur kognisi melainkan unsur afeksinya. Cerdas secara nilai dan angka-angka yang dihasilkan dalam raport, namun belum tentu secara spiritualnya mental dan kepribadiannya menjalannya dengan baik.

Untuk menerapkan pendidikan karakter yang baik, hendaklah mengandung tiga unsur pokok sebagaimana didefinisikan oleh Ryan dan Bohlin, sebagaimana dikutip dari Guntur Cahyohono, mangandung tiga unsur pokok, yaitu mengetahui kebaikan (knowing the good), mencintai kebaikan (loving the good), dan melakukan kebaikan (doing the good). Dalam pendidikan karakter, kebaikan itu sering kali dirangkum dalam sederet sifatsifat baik. ${ }^{20}$ Cahyo menyebutkan, sebuah proses pendidikan bisa dikatakan berbasis karakter apabila telah mewujudkan Sembilan pilar pendidikan karakter, yang terdiri dari: (1) cinta Tuhan dan segenap ciptaan-Nya, (2) kemandirian dan tanggung jawab, (3) kejujuran dan amanah, (4) hormat dan santun, (5) dermawan, suka tolong menolong, gotong-royong, dan kerjasama, (6) percaya diri dan kerja keras, (7)kepemimpinan dan keadilan, (8) baik dan

20 Guntur Cahoyono, Pendidikan Karakter Perspektif Al-Quran dan Hadist, AL-ASTAR, Jurnal Ahwal al-Syahsiyah dan Tarbiyah STAI Mempawah, Volume V, Nomor 1, Maret 2017. 
rendah hati, (9) toleransi, kedamaian, dan kesatuan.

Implementasi pendidikan karakter dalam Islam tersimpul dalam karakter pribadi Rasulullah SAW. Dalam pribadi Rasul, bersemai nilai-nilai Ahlak yang agung dan mulia. Al Qur'an surat Al-Ahzab: 21, yang artinya "Sesunggubnya telah ada dalam diri Rasulullab suri teladan yang baik." Pada ayat tersebut dijelaskan bahwa pendidikan karakter dalam perspektif Al-Qur'an dan hadits, telah ada sejak zaman Rasul, di mana Rasulsendiri merupakan role model dalam pembelajaran. Sebab, tidak diragukan lagi bahwa semua yang ada dalam diri Rasulullah SAW merupakan pencapaian karakter yang agung, tidak hanya bagi umat Islam tetapi juga bagi umat di seluruh dunia. Dengan demikian, semakin jelas bahwa pendidikan gaya Rasulullah SAW merupakan penanaman pendidikan karakter yang paling tepat bagi anak didik.

Dalam perspektif Islam, tahapantahapan pendidikan karakter dimulai sedini mungkin. Sebagaimana dijelaskan oleh Rasulullah SAW dalam haditsnya:

"Anas berkata bahwa Rasulullah bersabda: Anak itu pada hari ketujub dari kelabirannya disembelibkan akikabnya, serta diberi nama dan disingkirkan dari segala kotoran-kotoran. Jika ia telah berumur 6 tabun ia didik beradab susila, jika ia telah berumur 9 tahun dipisabkean tempat tidurnya dan jika telab berumur 13 tahun dipukul agar mau shalat. Jika ia telah berumur 16 tahun boleh dikawinkan, setelah itu ayahnya berjabat tangan dengannya dan mengatakan, saya telah mendidik, mengajar, dan mengawinkan kamu, saya mobon perlindungan kepada Allah dari fitnah-fitnah di dunia dan siksaan di akbirat."(H.R. Ibnu Hibban).

Hadits di atas menetapkan tentang tahap-tahap pendidikan karakter. Menurut M. Furqon Hidayatullah, dari hadis di atas dapat diklasifikasikan beberapa tahapan pendidikan karakter sebagai berikut ${ }^{21}$ :

1. Tahap Penanaman Tauhid. Pada usia inilah awal pembentukkan karakter seseorang dibentuk. Sehingga mulailah dengan penanaman tauhid. Hal ini nampak dalam hadits Rasul: "Jadikanlah kata-kata pertama yang diucapkan seorang anak kalimat La Illaha illallah. Dan bacakan kepadanya menjelang maut, kalimat La Illaha illallah.” (H.R. Ibnu Abbas). Dari pernyataan hadits tersebut, nampak jelas bahwa Rasulullah SAW sendiri telah mengajarkan kepada para sahabat dan pengikutnya akan penanaman tauhid kepada generasinya sejak dini.

2. Tahap Penanaman Adab. Pada tahap ini anak mulai dididik budi pekerti, terutama yang berkaitan dengan nilainilai kejujuran. Kejujuran merupakan karakter kunci dalam kehidupan. Pendidikan kejujuran harus diintegrasikan ke dalam kehidupan keluarga, masyarakat, maupun sekolah. Jika nilai kejujuran dapat dilakukan secara efektif berarti kita telah membangun landasan yang kukuh atas berdirinya suatu bangsa.

3. Tahap Penanaman Tanggung Jawab. Tanggung jawab merupakan perwujudan dari niat dan tekad untuk melakukan tugas yang diemban. Perintah agar anak usia 7 tahun mulai menjalankan shalat, menunjukkan bahwa anak mulai dididik untuk bertanggung jawab, terutama terhadap dirinya sendiri.

4. Tahap Penanaman Kepedulian. Kepedulian adalah empati kepada orang lain yang diwujudkan dalam bentuk memberikan pertolongan sesuai dengan kemampuan. Anak usia 9-10 tahun adalah masa-masa anak bergaul dengan teman sebayanya, maka tidaklah keliru ketika masa itu anak mulai ditanamkan jiwa empati kepada orang lain, saling

${ }^{21}$ Hidayatullah, M. Furqon, Pendidikan Karakter Membangun Peradaban Bangsa, (Bandung: Yuma Pustaka) 2010. h. 34 
menghormati kepada yang lebih tua dan saling menyayangi kepada teman yang lebih muda.

5. Tahap Penanaman Kemandirian. Kemandirian ditandai dengan kesiapan dalam menerima resiko sebagai konsekuensi tidak mentaati aturan. Proses pendidikan ini dapat dilihat ketika usia anak 10 tahun belum mau shalat, maka Rasul memerintahkan pukullah dan pisahkan tempat tidurnya dari orang tuanya.

6. Tahap Penanaman Bermasyarakat. Bermasyarakat adalah simbol kesediaan seseorang untuk bersosialisasi dan bersinergi dengan orang lain. Pada tahap ini anak diajarkan beradaptasi dengan lingkungan, selektif dalam bermasyarakat.

Tahapan-tahapan yang demikian itu bisa saja didapatkan dalam wadah pendidikan formal amupun non formal. Lembaga pendidikan formal, mulai dari jenjang sekolah dasar hingga sekolah menengah atas (SMA) sederajat, perlu menanamkan nilai-nilai budi pekerti bagi siswanya dengan berlandaskan pada norma dan etika yang terkandung dalam ajaran agama Islam ataupun norma dalam kehidupan bermasyarakat. Pendekatan religius memiliki banyak dampak terhadap kehidupan remaja sebab tidak hanya menguatkan etika pergaulan antarsesama melainkan juga meningkatkan tingkat spiritual dan ibadahnya. Oleh karena itu, yang paling dasar dari semua tahapan tersebut ialah adab. Kenakalan remaja ini lebih banyak disebabkan oleh faktor adab yang kurang baik sehingga melakukan penyimpangan-penyimpangan.

Di sekolah, praktik penanam nilai-nilai religiusitas ini bisa dengan pelajaran agama dan atau kegiatan keagamaan serta pelatihanpelatihan. Fungsi dari kegiatan itu ialah untuk saling memingatkan dalam hal pemahaman-pemahaman terhadap nilai-nilai agama agar bisa meresap dalam diri. Sebagaimana telah disebutkan di atas, bahwa ada banyak hal yang bisa mempengaruhi jiwa sehingga perlu terus diasah agar tidak tumpul. Remaja yang masih dalam perkembangan juga menerima banyak informasi dan pengetahuan sehingga perlu disaring dengan baik agar tidak berdampak negatif terhadap dirinya. Di sinilah perlunya siraman nilai-nilai religius agar karakter religius tersebut tumbuh subur. Tesis yang menyatakan bahwa ada korelasi antara tingkat religiusitas dan kenalan remaja sejatinya memang benar bila dilihat dari sisi filosofis dan karakteristik kejiwaan dalam pandangan Islam.

\section{Penutup}

Kenakalan remaja dan religiusitas pada dasarnya memiliki korelasi yang kuat sebagaimana telah digambarkan di atas. Remaja yang masih dalam usia pencarian jati diri dan sangat mudah terpengaruh oleh faktor-faktor eksternal bisa melahirkan penyimpangan, baik dalam diri maupun dalam tindakan sehari-hari. Kenakalan remaja adalah bentuk penyimpangan tindakan karena faktor yang mempengaruhinya berdampak negatif. Oleh sebab itu, perlu ditanamkan nilai-nilai religiusatas dalam diri remaja agar untuk mengurangi dampak negatif atu menyimpang dari faktorfaktor yang mempengaruhinya. $\mathrm{Hal}$ ini sejalah dengan beberapa tesis yang disampaikan peneliti terdahulu bahwa terdapat korelasi antara remaja nakal memiliki karakter religius yang rendah dibandingkan dengan remaja yang tidak nakal dengan karakter religus yang lebih baik. Dalam menanam karakter religius ini, setidaknya perlu mencontoh pedoman pendidikan karakter yang telah diajarkan oleh Nabi Muhammad SAW dengan penekanan yang paling dasar ialah pengenalan tentang adab atau aklak.

Dari gambaran di atas, dapat ditarik kesimpulan perihal pentingnya membentuk mental remaja dengan karakter Islami. Pola pembentukannya bisa dilakukan dengan pendidikan formal ataupun nonformal. Namun yang paling penting dari pendidikan tersebut ialah pendidikan adab, pendidikan yang tidak hanya fokus pada kognisi melainkan juga pada afeksinya. Sejatinya, karakter religius ialah karakter yang membentuk diri menjadi remaja yang 
memiliki cinta pada Tuhannya, kemandirian, amanah, santun, dermawan, optimisme, toleransi dan rendah hati. Karakter remaja yang demikian, bisa terwujud apabila dilakukan dengan cara yang tepat, khususnya pendidikan di sekolah formal. Remaja juga perlu dibiasan melakukan pebuatan yang mencerminan nilai-nilai karakter religius seperti menolong sesama, peduli lingkungan, gotong royong, dan lain sebagainya.]

\section{DAFTAR PUSTAKA}

Amin, Ahmad, 1986, Etika (Ilmu Ablak), alih bahasa oleh Prof. K.H. Farid Ma'ruf, Jakarta, Bulan Bintang.

Ancok, D. \& Suroso, F.N, 2011, Psikologi Islami Solusi Islam atas Problem problem Psikologi. Yogyakarta: Pustaka Pelajar.

Aroma, I. S., \& Suminar, D. R. 2012, Hubungan antara tingkat kontrol diri dengan kecenderungan perilaku kenakalan remaja, Jurnal Psikologi Pendidikan dan Perkembangan, 1(2), 1-6.

Azizah, Nur, 2013, "Perilaku Moral dan Religiusitas Siswa Berlatar Belakang Pendidikan Umum dan Agama" Jurnal Psikologi, Volume 33 Number 2 (21 May 2013)

Cahoyono, Guntur, 2017, Pendidikan Karakter Perspektif Al-Quran dan Hadist, AL-ASTAR, Jurnal Ahwal al-Syahsiyah dan Tarbiyah STAI Mempawah, Volume V, Nomor 1, Maret 2017.

Daradjat, Zakiyah, 1990, Kesehatan Mental, Jakarta: CV Haji Masagung.

Hamzah Tualeka, Abd. Syakur dkk, 2012, Ablak Tasawnf, Surabaya: IAIN Sunan Ampel.

Haq, Ahmad Hifdzil, Yoke Suryadarma. "Pendidikan Ablak Menurut Imam AlGhazali" At-Ta'dib, Volume 10 Number 2 (8 December 2015) doi:http://dx.doi.org/10.21111/attadib.v10i2.460

Hidayatullah, M. Furqon, 2010, Pendidikan Karakter Membangun Peradaban Bangsa, Bandung: Yuma Pustaka.

James Draver, A Dictionary of Psychology, New York: Pengin Books, t.th.
Langgulung, Hasan, 1992, Teori-teori Kesehatan Mental, Jakarta: Pustaka AlHusna.

Moeljono Notosoedirjo, 2001, Kesebatan Mental: Konsep dan Penerapan, (Malang: Universitas Muhammadiyah.

Nasbi, Ibrahim. 2015. Filsafat al-Nafs dan Filsafat al-Ablak. Shaut al Arabiyyah, 4(1).

Patty , F., dkk, 1982, Pengantar Psikologi Umum, Surabaya: Usaha Nasional, 1982.

Pusat Bahasa Depdiknas, 2008, Kamus Besar Bahasa Indonesia, Jakarta: Pusat Bahasa Depdiknas.

Salim, Abdullah, 1986, Akblaq Islam, Jakarta: Media dakwah.

Sarwono, S.W., 2010, Psikologi Remaja, Jakarta: Rajawali Pers.

Tentama, Fatwa, 2017, "Achievement Motivation Training (AMT) Sebagai Upaya Mencegah Kenakalan Remaja" Prosiding (November 8, 2017). doi:10.31227/osf.io/ucqw9.

Utami, M, 2014, Religiusitas, Koping Religius, dan Kesejabteraan Subjektif. Jurnal Psikologi, 39(1), 46-66. doi:https://doi.org/10.22146/jpsi.6966 